\title{
CALL FOR PAPERS: NJL SPECIAL ISSUE
}

\section{Easy Language research}

\author{
Ulla Vanhatalo*, Camilla Lindholm and Tiina Onikki-Rantajäskö \\ University of Helsinki \\ ^Email for correspondence: ulla.vanhatalo@helsinki.fi
}

The second issue of Volume 45 (autumn 2022) of the Nordic Journal of Linguistics will be a special issue devoted to Easy Language research. The issue will be edited by Camilla Lindholm, Tiina Onikki-Rantajääskö and Ulla Vanhatalo.

The term Easy Language (Germ. Leichte Sprache, Swe. lätt språk, Finn. selkokieli; earlier EASY-TO-READ LANGUAGE) refers to a modified variety of a natural language that has been adjusted so that it is easier to read and understand in terms of content, vocabulary and structure. Easy Language has been primarily targeted at people who have various difficulties in understanding standard forms of language, for example, due to learning disabilities or neurocognitive disorders. One can also see a connection between Easy Language and Plain LANGUAGE (see International Plain Language Federation, https://www.iplfederation.org/), both aiming at simplifying language.

Although attempts to create understandable language have probably been around for a long time, the start of the Easy Language era in the European context can be dated back to the late 1960s, when the first easy-to-read Swedish materials were published. Significant milestones were reached in the 1990s, when the first recommendations for easy writing were published by The International Federation of Library Associations and Institutions (IFLA, https://www.ifla.org/) and Inclusion Europe. Since then, the target groups of Easy Language have been expanding, comprising people with various backgrounds and life situations. Ongoing changes in societies and legislation on accessibility are creating increasing need for Easy Language and research on the topic. Besides language studies, Easy Language is also of interest in many disciplines such as economics, health sciences, sociology and cognitive science.

While Easy Languages have been used in Europe and especially in the Nordic countries for decades already, only little linguistic research has been done until the last few years. The development and use of Easy Languages have been built on experience gained from practical work done with the target groups (Wengelin 2015). More recently, especially interesting cases have been seen in Germany, where development and research are currently carried on a large scale (e.g. Bredel \& Maaß 2016, Bock 2019, Maaß \& Rink 2019, Hansen-Schirra \& Maaß 2020).

In this call for papers of $N J L$, we invite research papers which take a variety of linguistic approaches to Easy Language. First of all, we want to learn how Easy 
Language can be conceptualised: Is it a linguistic variety or a system, or just texts that have certain characteristics? What kinds of varieties are referred to as Easy Language, how do they differ from natural languages? How do they work in theory and in practice? Papers may take a theoretical or an empirical focus, including, but not limited to: Easy Language registers and variation with respect to lexical, grammatical and textual aspects, questions relating to linguistic complexity, the relation between Easy, Plain and Standard Languages, intralingual translation, guidelines and recommendations, recipient design, aspects of reception and understanding regarding various target groups, accessibility from a linguistic point of view, Easy Language and second language (L2), asymmetrical interaction, and psycholinguistic aspects to Easy Language. Topics can be approached from the perspective of both written language and spoken interaction. The papers may use any language as research material, and all relevant theoretical or methodological approaches are welcome. While the papers may be theoretical by nature, there should be at least some discussion on the applicability of the results. While we particularly welcome papers presenting original research, we invite thorough review articles also.

The deadline for submitted papers is 1 November 2021. The reviewing process for papers will take place in winter 2021 - spring 2022, and the publishing decisions will be based on the reviews (this also applies to invited manuscripts). All submissions should be made through NJL's ScholarOne/Manuscript Central site https:// mc.manuscriptcentral.com/njl. Prior to submission, authors are asked to consult the Journal's Instructions for Contributors, at https://www.cambridge.org/core/ journals/nordic-journal-of-linguistics/information/instructions-contributors, and follow the manuscript formatting guidelines set out there.

Please contact Ulla Vanhatalo at ulla.vanhatalo@helsinki.fi if you have any questions about this special issue.

\section{References}

Bock, Bettina. 2019. „Leichte Sprache“ - Kein Regelwerk. Sprachwissenschaftliche Ergebnisse und Praxisempfehlungen aus dem LeiSA-Projekt [Easy-to-read German - no rulebook: Linguistic results and practical recommendations from the LeiSA project]. Berlin: Frank \& Timme.

Bredel, Ursula \& Christiane Maaß. 2016. Leichte Sprache. Theoretische Grundlagen, Orientierung für die Praxis [Easy Language: Theoretical foundations - a guide for practitioners]. Berlin: Duden.

Hansen-Schirra, Silvia \& Christiane Maaß. 2020. Easy Language Research: Text and User Perspectives. Berlin: Frank \& Timme.

Maaß, Christiane \& Isabel Rink. 2019. Handbuch Barrierefreie Kommunikation [Handbook of accessible communication]. Berlin: Frank \& Timme.

Wengelin, Åsa. 2015. Mot en evidensbaserad språkvård? En kritisk granskning av några svenska klarspråksråd i ljuset av forskning om läsbarhet och språkbearbetning [Evidence-based production of accessible language? A critical review of Swedish Plain Language guidelines from a psycholinguistic readability perspective]. Sakprosa 7(2), article 4. https://journals.uio.no/sakprosa/article/view/983.

Cite this article: Vanhatalo U, Lindholm C, and Onikki-Rantajääskö T (2021). Call for papers: Easy Language research. Nordic Journal of Linguistics 44, 1-2. https://doi.org/10.1017/S0332586521000019 